\title{
The Spirit of Seriousness and Decolonisation
}

\author{
Thomas Meagher \\ ORCID iD: https://orcid.org/0000-0002-9195-6723
}

\begin{abstract}
This article seeks to examine 'the spirit of seriousness', as articulated by JeanPaul Sartre and Simone de Beauvoir, as a problem for decolonial theory and philosophy. It gives an account of the spirit of seriousness from the vantage of existential phenomenology in general and then works through its relevance, by way of W.E.B. Du Bois, Lewis Gordon, and Sylvia Wynter, for a diagnosis of the colonial condition and Euromodern man. Thus, it argues that decolonisation is necessarily opposed to $a$ spirit of seriousness, the one manifest in the attitude of the coloniser which various colonial forms seek to impose upon the colonised. It then explores the seeming paradox that decolonisation calls for taking seriously commitments that might amount to a form of decolonisation that adopts the spirit of seriousness. Through a discussion of Frantz Fanon, this article argues that the project of decolonisation requires serious commitments that nonetheless reject the spirit of seriousness.
\end{abstract}

Keywords: Philosophical problems, existential attitude, Euromodern colonisation, racism

\section{The Spirit of Seriousness}

This article seeks to examine philosophical problems both descriptive and normative in nature regarding decolonisation. In order to do so, it examines a concept with both descriptive and normative significance in the existential phenomenology of Jean-Paul Sartre and Simone de Beauvoir: namely, the spirit of seriousness. I will give an account of the spirit of seriousness in order to try to spell out why an understanding of this existential attitude is significant for projects of decolonisation. The spirit of seriousness is an orientation toward values that treats them as ready-made, external impositions, rather than as 
productions of human freedom. Hence, the spirit of seriousness is a form of bad faith (in the Sartrean sense of mauvaise foi) about one's responsibility for what one values. Drawing upon Sartre, de Beauvoir, W.E.B. Du Bois, Lewis Gordon, Sylvia Wynter, and Frantz Fanon, I will explore how Euromodern colonialism and racism involve a form of the spirit of seriousness. Hence, I will contend that decolonisation is opposed to $a$ spirit of seriousness. However, this raises a thornier matter: decolonisation calls for taking seriously commitments that, in turn, pose acute tendencies toward indulging the possibility or temptation of a retreat to the spirit of seriousness. These commitments I will thematise in terms of the anti-colonial and the decolonial. I conclude by suggesting that this means that the project of decolonisation is an anguished one that, paradoxically, must be taken seriously while nonetheless rejecting the spirit of seriousness.

The two primary texts from which I derive my conception of the spirit of seriousness are Sartre's Being and Nothingness: A Phenomenological Essay on Ontology ([1943] 1992) and de Beauvoir's The Ethics of Ambiguity ([1947] 2015). We can start, then, with Sartre's phenomenological ontology of the irreducibility of being-for-itself into being-in-itself. Put in simpler terms, we may view the issue as pointing to this matter: the difference between what consciousness is - that is, the 'being' of consciousness - and what an object of consciousness is - that is, the 'being' of which consciousness is conscious.

The key ontological point is expressed by Sartre roughly along these lines: being-in-itself is what it is ([1943] 1992: 29). The being of an inkwell, to use Sartre's oft-repeated example, is not a matter of concern to the inkwell. The inkwell is what it is; its being is in the modality of being-in-itself. Human existence, though, raises the possibility of a different mode of being. What I do gives rise to what I am. This type of being Sartre terms being-for-itself. Being-for-itself, according to Sartre, is not what it is and is what it is not ([1943] 1992: 28): when I answer the question of what I am, in addition to whatever answer I give, I am also the being that is giving this answer, and by virtue of that 'giving', I am more than the answer given. Hence, the ontological characteristic of my consciousness is that of being-for-itself. My consciousness confronts the question of what it shall be. For Sartre, being-in-itself and beingfor-itself are ontologically incommensurable; they cannot be synthesised into a coherent whole. On this point, Sartre diverges from G.W.F. Hegel, from whom he takes the language of being-in-itself and being-for-itself. As Lewis Gordon points out, for Hegel, 'the in-itself-for-itself - Geist, interpreted as 
Absolute Spirit - is achievable not only ontologically but historically' ([1995] 1999: 27).

The Absolute in the Hegelian framework is that which by all appearances must be contradictory but is, through internal resolutions that remain opaque to us, coherent nonetheless. For Sartre, though, being-in-itself-for-itself remains an irremediable contradiction; it is an impossibility ([1943] 1992: 145n12). The Absolute is impossible - though human freedom can nonetheless imagine this impossibility as if it were not only possible but actual. Sartre is famous for expressing this point in terms of the impossibility of God ([1943] 1992: 140). The God who is the subject of Christian theodicy, for instance, would seem to manifest the ontological characteristics of being-in-itself-foritself. In theodicy, God is understood to be both omnipotent and omnibenevolent - that is, at once all-powerful and capable only of good. To be a powerful agent is, ontologically, in the terrain of the for-itself: power implies choice, and the being of one who chooses what to be is being-for-itself. But to only be good would seem to imply the register of being-in-itself. If God is good, it would seem that God is good in the way that an inkwell is an inkwell. God's goodness is not a matter of choice or even concern for God. This would seem to present a paradox, though, if God is understood to be omnipotent. Is not an all-powerful being powerful enough that it may choose to be bad?

The theodicean conclusion that God may be both omnipotent and omnibenevolent would seem to imply that God's being is such that it resolves the ontological tension between limitless power and invariant benevolence.

God is an Absolute in which apparent contradictions are opaquely resolved. Consciousness of God, of course, can nonetheless treat God as an initself-for-itself, regardless of whether one rationally avows the logical coherence thereof. Such consciousness we can term faith. Indeed, faith of some sort - as Immanuel Kant ([1787] 2007) sought to show - may be a necessary foundation for knowledge. But by the same token, faith may function as an assault on knowledge: I may regard what I know to be true as if it were false and what I know to be false as if it were true. This is what Sartre terms mauvaise foi or bad faith ([1943] 1992: 86 - 116). In bad faith, I am conscious of evidence in such a way that it functions non-persuasively despite the presence of adequate evidence (Sartre [1943] 1992: 113). I know my faith to be at odds with reality. Why would I do this? The Sartrean answer is that my freedom presents the ubiquity of anguish. In anguish, I am reflectively conscious of my freedom ([1943] 1992: 64 - 85). I realise that it is up to me to 
decide what to do and who to become. If I shrink from the responsibility this entails, then I may opt for a path of self-deception in which I deny the reality of my freedom. In bad faith, I may regard myself as merely a being-in-itself, and this offers the possibility of relief from anguish as the pain or discomfort of responsibility to choose can be evaded insofar as I may imagine myself to be beyond choice in the way that the inkwell is beyond choice. However, I still may confront persistent reminders of my capacity to choose.

An antidote can be found, though, in a further dialectical development of bad faith wherein I regard myself as a being-in-itself-for-itself. In such bad faith I define myself through a theodicean logic in which my capacity to make choices is avowed at the same time that certain choices are regarded as intrinsically impossible. In defining myself as if I were a being-in-itself-foritself, I believe I am good, or that I am bad, or that I am youthful or that I am philosophical, that I am artistic or I am scientific, and behold: each of my actions, chosen on the basis of this self-definition, appears plainly to be a manifestation of my identity. I am good, and each of my acts is good; I am scientific, and each of my beliefs are scientific; I am youthful, and each attitude I adopt must properly be the attitude of those who are youthful. My ontological prophecy can function in self-fulfilling fashion.

It would be a different matter, however, for me to express these characteristics as desired ones: I want to be youthful, I want to be scientific, I want to be good, etc. Such desire invites an anguished reflection: how can I be youthful, or scientific, or good? In bad faith, though, I may assert that I am what I desire to be, such that the choices through which this is manifest are not anguished ones but are simply my fulfilments of a fixed and unavoidable essence. The path to overcoming bad faith would seem, then, to call for me to understand myself as driven by desires to be this or that: I could defeat the tendency toward bad faith by insisting on understanding my acts as chosen in relation to values that are themselves chosen.

It is here where we can clearly outline the spirit of seriousness in its particularity: the spirit of seriousness is a form of bad faith about what is valued or desired. The spirit of seriousness treats values as if they were unchosen. In the spirit of seriousness, I treat what I value as if it were something that I must value. I would not be me if I didn't value it, or I would not be human if I didn't value it, etc. Sartre gives the example of bread: the 'serious man' eats bread not because he values its taste or nutritional facets but, simply, because to him bread is necessary for human life. We can point to much empirical evidence - 


\section{Thomas Meagher}

of those from communities that do not consume bread, or persons who have adjusted their diets because of coeliac disease, for instance - to show that it simply is not the case; our serious man is lying to himself about the necessity of bread.

For Sartre, he does so in order to evade anguish: to take responsibility for what he values displeases him, so he opts to regard his values as matters that are not up for debate. He values what he values, and there is nothing more to say on the matter - or so he claims. From the perspective of a Sartrean ontology, a being-for-itself is condemned to make choices shaped by values that are themselves chosen. There are no unchosen values, nor are there acts that do not reflect one's values in some way. The spirit of seriousness, then, in regarding its values as unchosen, is in bad faith. Rather than being the contingent products of my ongoing axiological agency, in the spirit of seriousness I regard my values as if they simply are what they are. The spirit of seriousness is thus a sophisticated effort to define oneself in relation to the in-itself-for-itself. In bad faith, I may define myself directly as God or as a similarly Absolute mode of being, e.g. a demonic embodiment of a 'pure evil'.

Yet I may also define myself indirectly as one who is judged by God. Bad faith can appeal to the in-itself-for-itself by manifesting its desire for fealty to God. In doing so, bad faith can manifest a form of what I call Ideal Shame (Meagher 2018: 117). I capitalise this term because it is ultimately neither normatively ideal nor actually shame. For Sartre, shame occurs when I see myself being seen. In shame, I see myself as a being-in-itself because I see what I am to another. I see myself as an object of another's consciousness. You see me as lazy, and seeing myself seen as lazy, I see this laziness that I am for you. This implies that, read rigorously, shame in the Sartrean sense is normatively neutral: shame is equally present where I see myself through your loving gaze as when I see myself through your despising gaze. Crucially, shame may thus function as an antidote to bad faith: if I have persisted in believing in my superior productivity despite all evidence to the contrary, the shameful apprehension of my laziness through an encounter with someone who regards me as lazy may snap me out of my stupor. Shame can spur me on to pay attention to the evidence. But by the same token, I can appeal to shame to maintain my self-deception: I can seek out being seen by you because I know that you will see me in the way that I want to see myself. Shame, thus, can serve either an interruptive or a reinforcing function with regard to bad faith. 
If we move from shame to Ideal Shame, this involves a shift from seeing myself as seen by another to seeing myself as seen by an imagined other. The other that judges me is not, then, a fellow being-for-itself but is a projected being-in-itself or a projected in-itself-for-itself. In Ideal Shame, I sit in judgment by God. In shame, my adjudicator is free, and I would be wise to remember that it is the values chosen by this other that shape how she or he sees me. In Ideal Shame, though, my adjudicator is dictated by values. Such dictation implies a corruption of the notion of value, though, since values become material features of the world, beings-in-themselves. Ideal Shame is thus a masquerade in which I project a God who can judge me, so that I can be relieved of the anguish of judging myself. The problem, though, is that I have projected this God, such that I have not taken leave of that anguish but have merely disguised it. In the spirit of seriousness, I adopt the perspective of Ideal Shame, in which I am always judged by an absolute standard of value that I regard as external to me, though it is ultimately my own choices that make this standard function as if it were absolute. Values internally and contingently adopted are regarded as if they were externally and inescapably imposed.

How does such seriousness manifest? In The Ethics of Ambiguity, de Beauvoir provides an existential typology given in terms of five figures: the serious man, the sub-man, the nihilist, the adventurer, and the passionate man. The serious man we have already sketched through Sartre: in de Beauvoir's words,

The serious man gets rid of his freedom by claiming to subordinate it to values which would be unconditioned. He imagines that the accession to these values likewise permanently confers value upon himself. Shielded with 'rights,' he fulfils himself as a being who is escaping from the stress of existence ([1947] 2015: 49 - 50).

He is emboldened by a sense of Ideal Shame that, by positing an external Godfigure that stands in judgment of him, relieves him of the anguish of working out values of his own. The God-figure of the serious man, though, need not be a theological or religious conception of the divine, since the function of Ideal Shame can be converted into secular terms. Hence, the serious man may stand in relation to secular ideals of right, of patriotism, capitalism, colonialism, and so on.

The sub-man is a variation on the serious man. For the sub-man, the 


\section{Thomas Meagher}

source of Ideal Shame lies not in the transcendent (God, nation, race, etc.) as it does for the serious man, but lies instead in the figure of a concrete other. The sub-man yearns for a reality in which a fascist or totalitarian leader ascends and can function as 'dictator' not only of a state but of the values of the subman. He is suffused with a masochistic desire for an indispensable hegemon, because this presence will relieve him of the anguish of his acting freely upon the world. Yet the sub-man's embrace of a concrete other, a leader or an abuser, implies the projection of divine characteristics onto this other, such that they function for him as does God or the projection of transcendent values for the serious man.

The nihilist is the ironic counterpart to the serious man, and often evolves out of an existential position of seriousness. The nihilist finds no validity in the transcendent and from this concludes that all values are valueless. Because there is no value in values, the nihilist rejects all values, and is thus thrust into a project of negation that seeks, in some sense, to annihilate the world. The serious man who confronts, through failure or calamity, the limits of his beliefs often spirals into nihilism, concluding that, because his values proved to be rubbish, all values must be so. The nihilist, then, embraces his freedom insofar as he does not, like the serious or the sub-man, regard himself as yoked to this or that source of value, but his embrace is circumscribed by his inability to establish positive values of his own.

The foil of the nihilist is the adventurer. The adventurer is like the nihilist in rejecting seriousness; the adventurer does not see himself as serving transcendent ideals. The adventurer regards life as a journey that is worthwhile for the experience, for its swashbuckling exploits, even if in the end there are no values to be served, no destination by which to judge the journey. The problem with the adventurer, as de Beauvoir lays it out, is that his passion for adventure values the experience of freedom rather than freedom itself. As such, the adventurer becomes the useful idiot of the powerful, who are willing to bankroll his exploits so that he can enjoy the journey and that they can enjoy the fruits thereof. He rejects the project of arriving at a chosen destination, but in so doing has his destination chosen for him.

The passionate man appears, at first, to embrace his freedom. He does not shy from the anguish of choosing what to value: rather, he defines all others in terms of their value to him. For the passionate man, what is valuable in the world is whatever is valuable to him. Whereas the serious man finds value in the external and transcendent, value for the passionate man is an internal 
production. Rather than standing in judgment from a source of Ideal Shame, the passionate man regards himself as if he were the source of Ideal Shame. It is in the eyes of the passionate man that others should locate their true value. Hence, the passionate man is the existential type who most literally manifests the desire to be God: his perspective is the ideal perspective not because of the value of his choices but because his being necessitates as such.

What each of these existential types - the serious man, the sub-man, the nihilist, the adventurer, and the passionate man - holds in common is an attitude toward values in which a responsibility for values vacates the scene. They are in bad faith about their capacity to choose what to value. The serious man and the sub-man do so by holding an external source of value as inevitable; the nihilist and the adventurer do so by holding a valid source of values as impossible; and the passionate man does so by regarding himself as an intrinsically sufficient source of values, such that it is indifferent which values he has chosen because the point is that he has adopted them. Although of these five types only one is named with explicit reference to seriousness, as I interpret it, all five are different manifestations of the spirit of seriousness. Each evinces a bad faith denial of axiological responsibility.

\section{The Seriousness of Colonial Man}

One of the paradigmatic examples given by de Beauvoir of the serious man is the colonial administrator.

The colonial administrator who has raised the highway to the stature of an idol will have no scruple about assuring its construction at the price of a great number of lives of the natives; for, what value has the life of a native who is incompetent, lazy, and clumsy when it comes to building highways? ([1943] 2015: 53).

He is one who must build the highway; his acts are imagined to be governed by absolute imperatives of values that lie beyond him, despite the reality that he is one who ultimately chooses to regard those values as absolute. He acts for 'Civilisation', or for Europe, or for Mother England or France or the United States of America (USA), or for Science or for Democracy, or even simply for God or for Christ. He colonises in the name of serious, unconditioned values that, he asserts, lie external to him and dictate what his acts would ideally be. 


\section{Thomas Meagher}

This portrait accords with those given by a variety of theorists of racism, colonialism, and decolonisation. For instance, an attitude of seriousness is diagnosed by W.E.B. Du Bois in his classic essay, 'The Souls of White Folk' included in Darkwater ([1920] 1999: 17 - 29). There whiteness is defined as 'the ownership of the earth forever and ever, Amen!' (18). Indeed, Du Bois worries there that the national culture of the USA tends toward taking whiteness as an axiological absolute. Whiteness, he contends, is an ideal that lowers and demeans humankind; but societies premised on service of this ideal function so as to generate a form of hegemony or overlapping consensus for which whiteness is, simply, God.

This dynamic was manifest in the problem of double consciousness. For Du Bois, as stated clearly in 'The Conservation of the Races' ([1897] 1971), race is a matter not of phenotype but of shared ideals. If race is a 'social construction', it is one constructed in reference to posited ideals of what the society ought to be - ideals, in Euromodern contexts, in which whiteness figures as divine and blackness as demonic. Double consciousness as experienced in the USA emerges through a situation of warring ideals: to have been educated and cultivated such that one sees oneself as a typical person abiding by the society's typical ideals and mores - hence, abiding by a white normativity - but to also experience oneself as black in relation to the demands of whiteness, and hence, to be pushed toward an existential conflict as to the desirability or undesirability of whiteness (Du Bois [1903] 2018: 3; Henry 2016: 34-7). In short, such double consciousness confronts whiteness as a source of Ideal Shame and must deal with the apparent contradiction that, on the one hand, one ought to do as whiteness prescribes but that, on the other hand, as a black person one may never fulfil whiteness's demands since one remains black and hence antithetical to the ideal.

Lewis Gordon, in Bad Faith and Antiblack Racism ([1995] 1999) reinforces this analysis. There, he contends that racism is a form of the spirit of seriousness in which the white anti-black racism is manifesting the desire to be God. He is asserting himself as an Absolute source of value. As in Du Boisian double consciousness, a consequence is the production of black-based anti-black consciousness: because the social world is one premised on an aversion to the freedom of black consciousness - including the freedom to construct and fulfil values - black people develop ways of seeing the world and themselves through a projected white consciousness.

In short, colonialism seeks to build a world in which the perspective 
of the coloniser is treated as Absolute. Hence, colonialism colonises both the freedom of the coloniser and the freedom of the colonised. Each becomes an instrument of the colonial perspective. In terms of Beauvoir's existential typology, the fundamental relation of colonialism could be characterised in terms of producing the coloniser as the serious man and the colonised as the sub-man. The ideal of colonialism is to produce colonisers who regard themselves as needing to advance the colonial project and colonised people who regard themselves as needing to acquiesce to it, savages who have finally encountered the God for whom they had laid in wait. ${ }^{1}$

It would be superficial, though, to regard colonialism as only desiring the production of these two types. To begin with, the framework of colonialism suggests in some sense the presence of the passionate man, although perhaps one collectivised in crucial senses. That is to say, if the serious man sees the colonial project as necessitated by the value of civilisation, he may nonetheless be in league with those who see the colonial projected as necessitated by the whim of European Man, a passion project, as it were. How to make sense of Euromodern colonialism, after all, without accounting for the way in which at the bottom it rests upon asserting the actual desires of concretely existing white people as mattering, to the exclusion of the desires of people of colour? Colonialism, in that sense, can be understood as a project to bring about a serious world governed by a coalition of passionate men. This effort, though, need not rest upon a strict division of the world wherein all the colonisers are serious and all of the colonised are sub-men. For one, we know that it is not disruptive to the colonial project for there to be sub-men among the colonising societies. Fascist and totalitarian configurations within the colonial powers are compatible with their colonial ambitions; the production of white sub-men is compatible with colonial aims. For two, the type characterised by Beauvoir as the adventurer can be seen as part and parcel of the colonial endeavour.

Indeed, the colonial project desires not only to have adventurers culled from the colonising society but ones drawn from the colonised society as well: colonised people willing to enlist in the armies and forces of the colonisers are welcome, regardless of whether or not they take the colonial project seriously. Likewise, the production of nihilism among the colonised is clearly

${ }^{1}$ Indeed, even avowedly anti-colonial readings of the colonial situations may presuppose the latter, as Frantz Fanon shows in chapter four of Black Skin White Masks ([1952] 1967: 83 - 108). 


\section{Thomas Meagher}

commensurate with the colonial project. In short, then, while the seriousness of the colonial administrator may be an ideal type for colonialism, colonialism benefits across the board from a variety of dispositions of seriousness so long as they do not upset the colonial apple cart. We can thus state that colonialism rests upon a spirit of seriousness, and it follows, then, that decolonisation must at least be opposed to $a$ spirit of seriousness. Colonisation is the effort to impose a symbolic expression of the in-itself-for-itself, an aesthetic rendering of a God who, by a colonisation of the quotidian axiology of the lifeworld, is to serve as a source of Ideal Shame for all.

Here we may note that the process of colonisation is a multifaceted and longue durée process. Hence, as Sylvia Wynter (2003) argues, this process involves a 'transumption' of earlier Gods into newer ones. By 'transume' we mean here to carry over through a transformative preservation; God is, as it were, given a series of successive makeovers as colonisation unfolds. Hence, we have a transformation from

(1) an earlier period in which the axiology of Christendom mandated wars of evangelisation by appeal to God as a theological absolute; to

(2) a middle period in which Christendom becomes 'Europe', driven by the mandate of wars of colonisation through appeals to the rationality of homo politicus as a philosophical absolute; to

(3) a later period in which Europe is globalised and fights wars for coloniality through appeals to the natural selection of homo oeconomicus as a scientific absolute.

Each of these is a form of the spirit of seriousness: 'Man', to use Wynter's term, functions as the in-itself-for-itself who can be regarded as a source of Ideal Shame. 'Man' functions as the secular God-figure anchoring a Euromodern spirit of seriousness, and the serious man functions as an acolyte of this Man.

Yet at the same time, there is an apparent contradiction insofar as Euromodern man is taken to be instantiation of Man and not merely servant. Hence, there is a theodicean logic - one that Wynter terms 'biodicean' (Wynter 2006; Gordon 2013) - in which Euromodern man functions as both God and servant, a fusion of the serious and the passionate understood by himself and his society on the model of the Absolute.

Colonialism thus stands in relation to the very core of the spirit of seri- 
ousness. The spirit of seriousness is concerned, most fundamentally, with denying human freedom to construct values. This does not mean that the spirit of seriousness pre-empts such construction: indeed, the serious man is constantly at work articulating the rationalisations for his acts. The key, though, is that he does so through an obscurantist logic in which these values he synthesises are regarded as emerging from outside of him. So, too, for a serious society: it is hard at work producing values, all the while it seeks to articulate how such values are transcendent. The serious man is not afraid of values, nor of the responsibility of fulfilling them, but is afraid of responsibility for constructing them. The coloniser thus acts in the name of God, or civilisation, or the flag; the coloniser sets up social and economic systems in which it is not these administrators or those agents of capital who are choosing to value human degradation, but 'The Market' - neoliberals always acting, it would seem, on the basis of a distant divinity. Colonialism proper is premised on regarding the autonomy of one nation as if it were transcendent: colonialism seeks to produce a serious world governed by the dictates of the Passionate Nation. In its Euromodern incarnation, this is given a peculiarly political expression, as the coalition of colonisers sought to erect compacts recognising each other's right to colonial power.

Euromodernity emerges as the serious project of passionate nations, working in concert to colonise the globe. At the meta-level, this amounts, as Wynter's argument $(2003 ; 2006)$ suggests, to the construction of a passionate man par excellence - European man, white man, modern man, etc. He is here the autonomous individual, licensed to inflict his passions upon a servile world, and he is there the transcendent value (civilisation, reason, science, philosophy, modernity, market) to which all agents must seriously subscribe. He is, in short, the Absolute - and his contradictions are to be apprehended in the wondrous aesthetic consciousness of religious belief rather than the sober rationality of a critical philosophy. He is Colonial Man, serious in the project of building a world governed by the passions of colonial men, yet imbued with the narcissism of the passionate man such that his seriousness is above all a matter of serving himself.

\section{Coloniality and Decolonisation}

The antidote to this colonial spirit of seriousness would thus seem to lie in decolonisation. In decolonisation, the autonomy of the individual nation gives 


\section{Thomas Meagher}

way to a heteronomy of interests and agents. In decolonisation, the colonised acts upon the coloniser; the colonised inflict their will. Decolonisation thus is only coherent on the grounds of its opposing the seriousness of the coloniser, and taken to its radical conclusion, decolonisation seeks to build a world in which the seriousness of Colonial Man becomes impossible. Decolonisation, as Frantz Fanon writes, 'is quite simply the replacing of a certain 'species' of men by another 'species' of men' ([1961] 1963: 35). Decolonisation obliterates the serious Colonial Man and any vestiges of the Colonised sub-man that he had managed to erect. Seriousness - a bad faith about one's responsibility for values - is thus part and parcel of the colonial project, and the spirit of seriousness undergirding the colonial project is one that decolonisation must oppose.

But this raises a crucial question: can opposition to a spirit of seriousness avoid becoming a spirit of seriousness in its own right, or is seriousness an intractable existential problem? Must decolonisation, in short, replace the serious Colonial Man with the serious Decolonial Man? Fanon's detailed phenomenology of decolonisation in The Wretched of the Earth ([1961] 1963) complicates and unsettles such a claim. The anti-colonial struggle, we find, involves a seriousness parallel to that of the coloniser. The colonised commit to a violent project of displacing the coloniser, one undertaken in light of the utmost seriousness of bringing about the coloniser's exit. If the coloniser seeks to bring about the serious world of the passionate man, then the anti-colonial struggle is governed by the serious imperatives of the passion of the colonised.

The look that the native turns on the settler's town is a look of lust, a look of envy; it expresses his dreams of possession - all manner of possession: to sit at the settler's table, to sleep in the settler's bed, with his wife if possible. The colonised man is an envious man. ...[T]here is no native who does not dream at least once a day of setting himself up in the settler's place ([1961] 1963:39).

As the dialectics of decolonisation evolve, dynamics of nation and class emerge or are reconfigured so as to recapitulate these matters. The birth of the postcolonial nation, Fanon shows, becomes yoked to the rise of a petitbourgeoisie, who are empowered, in turn, to cut deals with the coloniser in the guise of a serious project - for the national economy, say - that is, in essence, a ruse for the passionate project of the mutual enrichment of elites. The new 
nation is caught up in the vicious cycle of trying to equal and surpass Europe, precisely through mechanisms of collaborating with a Europe hell-bent on retaining its status. Ironically, it is in these dynamics that the hardened seriousness of the coloniser begins to wane. The coloniser comes to accept that he need not be installed absolutely as sovereign. The coloniser recognises the postcolonial elites not as snivelling toadies but as fellow businessmen, entitled to negotiate a deal. The passion of Colonial Man for capital, for power, and for control does not subside, but it accepts a configuration in which this passion cannot function as an unconditioned, supraordinate value governing the sum total of all transactions in the developed world-system. Reading The Wretched of the Earth as a Fanonian work in the existential phenomenology of decolonisation, we may say that the issue it raises acutely is that of the relationship between colonialism and coloniality. Fanon called for leaving Europe behind, for abandoning its 'Greco-Latin pedestal' ([1961] 1963: 46). He sought, in short, a movement beyond not only colonialism but coloniality, where the latter speaks to a broader configuration of values inaugurated by colonialism but durable enough to persist after the formal transfer of sovereignty. One might conclude, then, that decolonisation implies a double opposition: decolonisation is against both colonialism and coloniality. This may at first blush seem a simple matter, given the clear relationship between colonialism and coloniality. Let us try, though, to demonstrate the complications such a double opposition suggests.

Colonialism involves the structure of the Absolute. It seeks to impose the will of the coloniser, or of the colonial nation, such that trespassing upon his desired ends and means is equivalent to a violation of the transcendent. The coloniser ascends, in the values of the world colonialism creates, to the status of the divine. Opposition to colonialism thus must take the form of what I will call here the anti-colonial. The anti-colonial is given over to the project of displacing the colonial power. The displacement of the coloniser functions for it as an absolute value: as Fanon writes,

the primary Manicheism which governed colonial society is preserved intact during the period of decolonisation; that is to say that the settler never ceases to be the enemy, the opponent, the foe that must be overthrown ([1961] 1963: 50 - 51).

The absolute nature of this opposition is non-negotiable for the anti-colonial. 


\section{Thomas Meagher}

Calls are made, of course, for a moderation of strategies and tactics; there is a moral appeal to humanistic values, to the imperative of a non-violent approach. The problem, though, is that once such appeals are taken seriously, we have ventured out of the territory of the anti-colonial. The moral cleanliness of the colonised is afforded greater value than the overthrow of the colonial system. For the anti-colonial, the demand of the coloniser's ouster functions as Absolute; it is the source of Ideal Shame against which all acts must be judged.

Coloniality, though, is more insidious than colonialism. Colonialism proffers a well-ordered social world in which all and sundry understand that it is the coloniser who is to rule. Coloniality, by contrast, involves a world structured by colonial ends but confused about their meaning in the present. On the one hand, coloniality involves the agents of those who avow the value of coloniality. There are those who take relatively seriously that it is Euromodern Man who ought to continue to rule, and although they are softer in their approach than Colonial Man had been - they are conducive to compromise and to recognising the humanity of those embodying darker hues - they nonetheless take up the bulk of the serious values of their colonialist predecessors. On the other hand, coloniality also involves agents who reject and repudiate colonialism, who are shaped by a genuine existential commitment to build the world anew. Coloniality seeks, in short, to configure relations in such a way that even those explicitly committed to decolonisation nonetheless maintain the system of coloniality. Hence, the existential problem confronting those committed to decolonisation within conditions of coloniality is that it is not necessarily the case that one committed to overturning the colonial is clear on the precise contours of the colonial landscape or on the precise ways in which the colonial past shapes their efforts to build a post-colonial future.

The tragedy of 'man' - as both Fanon ([1952] 1967: 10, 231) and de Beauvoir contended ([1947] 2015:37) - is that he was once a child, and hence confronts the melancholia of being shaped by desires that the adult cannot fully grasp. The tragedy of the post-colonial adult stems, as it were, from the trauma of a colonial childhood. There is a psychological drama here wherein the one who is committed to overcoming a past of colonialism and a present of coloniality may nonetheless have been shaped and structured by colonial values.

It is in this drama that the impulse of the decolonial emerges. The decolonial lives a commitment to revolutionise the values of the world. The decolonial does not seek to return the world to a pre-colonial past, but the decolonial is nonetheless absolutely committed to the project of building a non-colonial 
future. Such a future is one in which, as Fanon puts it, 'the tool [shall] never possess the man' ([1952] 1967: 231). Coloniality, as colonialism's residue, is that which the decolonial is hell-bent on removing. The decolonial must take seriously, then, the project of building a world in which the power of Colonial Man has been diminished to zero. And because the power of Colonial Man has resided in a revolution of values - in 'his' ability to spread the gospel, to reconfigure what human beings the world over want - the decolonial lives an Absolute commitment to overthrowing the values of the colonial. If these are, respectively, the natures of the anti-colonial and the decolonial, then what is the precise relationship between these two terms and the broader one under discussion thus far, decolonisation? It would appear the anti-colonial and the decolonial are jointly necessary for decolonisation. If there is simply the persistence and victory of the anti-colonial impulse, then the coloniser is displaced from sovereignty, but the coloniser's influence - in shaping the nature of post-colonial states and, indeed, worlds - remains. That is to say, the anti-colonial is insufficient for decolonisation if decolonisation demands a revolution in values.

The anti-colonial is, tragically, compatible with residual coloniality. This would suggest that the decolonial is necessary for decolonisation. Indeed, where colonialism has subsided and only coloniality remains, it may appear that the decolonial suffices for decolonisation: it brings about the clean-up where the anti-colonial has killed the beast, and at this point, the anti-colonial may simply be dismissed from the scene. A problem, though: the shift from colonialism to coloniality does not by necessity bring with it the finality of such a shift. Indeed, coloniality's affection for a colonialist past makes it conducive to a revival. In this regard, the purity of the decolonial impulse can be an impediment to its underlying mission. The decolonial confronts a drama akin to that of the adolescent or adult who resolves, 'I will never be like my parents!' The decolonial resists whatsoever shall appear to be a recapitulation of the values of the coloniser. Colonial Man was violent, so the decolonial announces its commitment to non-violence; Colonial Man spoke of Civilisation, of Science, of Democracy, so the decolonial announces its wholesale rejection of these ideals; Colonial Man said that he and his affiliates retained the exclusive right to speak and be heard, so the decolonial comes to respect the right of all to be heard with eager and approving ears. The decolonial takes up, in brief, the serious project of abandoning the values of Colonial Man altogether. 


\section{Thomas Meagher}

The pitfalls of the decolonial can thus be summarised in terms of two categories. First, the decolonial may create the conditions for the exacerbation of coloniality and/or the return of dimensions of outright colonialism. By repudiating colonial values, the decolonial forswears many of the tools that the anti-colonial may effectively be able to take up in order to counter neo-colonial encroachments. Second, the decolonial may find itself unintentionally manifesting precisely the characteristics of Colonial Man; the decolonial confronts the possibility of the return of the repressed. In brief, because Colonial Man is serious about retaining coloniality and taking up every possible avenue of return toward colonialism, the anti-colonial is indispensable to decolonisation, and cannot be dissolved in the seriousness of the decolonial. But the seriousness of the anti-colonial is a near-guarantee of a return to the values of Colonial Man, insofar as it must - by means of being a steadfast project of opposition - be subject to the modes of intentional manipulation to which Colonial Man may always make recourse in order to reinforce his position. The temptation, then, would be to simplify the meaning of decolonisation by developing a configuration of the anti-colonial and the decolonial wherein they can be neatly synthesised, wherein they can be fused into the ideal embodiment of decolonisation. But is not such a call, ultimately, a demand for the Absolute - for the impossible synthesis of two characteristics that nonetheless bear an ineffaceable tension?

The tragedy of decolonisation is that it is drawn to desire a pure, authentic opposition to the coloniser - to the coloniser's power, as in the anticolonial, or to the coloniser's values, as in the decolonial. Yet colonialism is precisely a force engineered to nullify the purity and authenticity of its victims, let alone its perpetrators. Colonialism seeks to produce a world in which all who live are complicit in colonial power. To live in such a world is to serve, whether as volunteer or conscript, at its discretion. Coloniality, in turn, seeks to sublimate this complicity into an incessant relation of profitability for the few, wherein the denial of an ongoing project of colonialism functions to ensure the persistence of colonial outcomes.

In short, what decolonisation must critically confront is the issue of a desire for either the anti-colonial or the decolonial - or an imagined, impossible synthesis of the two - to function as a source of Ideal Shame. To hear many proponents of decolonisation speak, the function of decolonisation is akin to the function of the divine. Decolonisation calls, on that model, for the utmost seriousness: to be non-colonial functions as a transcendent ideal, impervious 
to philosophical attack. Within that framework, we are called upon to build the serious world of the decolonial passion. The desire to be non-colonial is regarded as unassailable. A simple criticism may be issued: if this is the function of decolonisation, then it remains a recapitulation of a crucial element of colonialism.

\section{Conclusion - Toward Decolonisation, Against the Spirit of Seriousness}

I submit, then, the following conclusion: that not only is decolonisation opposed to $a$ spirit of seriousness - the seriousness of Colonial Man - but that decolonisation is opposed to the spirit of seriousness in general. The paradox that this would seem to present is that one cannot engage in successful projects of decolonisation without taking seriously anti-colonial and/or decolonial commitments. For the purposes of this or those acts of decolonisation, the anticolonial impulse must be regarded as sufficiently justified, or the decolonial impulse must be regarded as sufficiently justified. This suggests that essential to the project of decolonisation is a sense of maturity in which, I have argued, one must take commitments seriously without a collapse into the spirit of seriousness (Meagher 2018).

Paradoxically, then, the commitment to decolonisation calls for a commitment to discovering and synthesising values that would call for the teleological suspension of decolonisation. To have achieved decolonisation means to have put in place values whereby other things could matter more than the continued imperative of effacing colonial residues. But, crucially, this does not entail that the project of decolonisation can be done away with altogether and replaced with the project or projects that would be its successors - for, indeed, to accept that conclusion would be to accept that one knows, in advance, which values are the sticky remains of colonialism and coloniality and which are not; it would be to recapitulate the path that besets the decolonial. If the destination of decolonisation points to a further destination beyond it, this does not imply the irrelevance of the journey itself.

If this conclusion is correct, then it means that decolonisation is necessarily an anguished project. The spirit of seriousness offers relief from anguish: one knows that one is right, or that one has fulfilled one's duties, and need not take responsibility for evaluating the schema of rights and duties that has animated one's acts. The scam of colonialism is that it at once would seem 


\section{Thomas Meagher}

to take on a profound responsibility for the world - by installing Colonial Man as undisputed ruler and hegemon - and yet to discount such responsibility by the same stroke, since Colonial Man may always appeal to transcendent values that mean he is merely enjoying what is rightfully his and discharging his rightful duties. His structure is one of domination, in which the acts of the master are a matter of license and are thus up to his arbitrary, passionate whims. The master and the coloniser may speak of 'taking responsibility' for the slave and the world, respectively, but through a trick of bad faith, each takes this to mean a reduction rather than intensification of anguish. They are emancipated to do as they please, regardless of the values of the dominated, who for them do not function as sources of shame.

The project of decolonisation would be more comforting if it could reenact these dynamics. It would be comforting if the anti-colonial impulse meant one was licensed to revolt by all means necessary without responsibility for what one wreaks. It would be comforting if the decolonial impulse meant that one was licensed to live through the purity of unassailable values that preserve one's goodness and innocence even as neo-colonial tempests erupt all around. To bring about a world that is no longer colonial, though, means to bring about a world in which humanity seizes responsibility for its values. Such a project is an anguished one - and it is this grappling with the anguish of decolonisation that each of us must take up in order to fulfil Fanon's call ([1961] 1963: 316) to set afoot a new humanity.

\section{References}

De Beauvoir, S. [1947] 2015. The Ethics of Ambiguity. Frechtman, B. (trans.). New York: Philosophical Library.

Du Bois, W.E.B. [1897] 1971. The Conservation of the Races. In Lester, J. (ed.): The Seventh Son: The Thoughts and Writings of W.E.B. Du Bois. New York: Random House.

Du Bois, W.E.B. [1903] 2018. The Souls of Black Folk: Essays and Sketches. Alexander, S.L. (Introduction.). Amherst/ Boston: University of Massachusetts Amherst Libraries and University of Massachusetts Press. https://doi.org/10.2307/j.ctv346v0g

Du Bois, W.E.B. [1920] 1999. Darkwater: Voices from Within the Veil. Dover

Thrift Edition. Marable, M. (Introduction.). Mineola, NY: Dover Publications Inc. 
Fanon, F. [1952] 1967. Black Skin White Masks. Markmann, C.L. (trans.). New York: Grove Press.

Fanon, F. [1961] 1963. The Wretched of the Earth. Farrington, C. (trans.). New York: Grove Press.

Gordon, L.R. [1995] 1999. Bad Faith and Antiblack Racism. New York: Humanity Books. https://doi.org/10.1007/978-94-015-8408-1_8

Gordon, L.R. 2013. Race, Theodicy, and the Normative Emancipatory Challenges of Blackness. South Atlantic Quarterly 112, 4: 725 - 736. https://doi.org/10.1215/00382876-2345252

Henry, P. 2016. Journeys in Caribbean Thought: The Paget Henry Reader. Gordon, J.A., L.R. Gordon, A. Kamugisha \& N. Roberts (eds.). New York: Rowman \& Littlefield International.

Kant, I. [1787] 2007. Critique of Pure Reason. Smith, N.K. (trans.). New York: Palgrave MacMillan. https://doi.org/10.1007/978-1-137-10016-0

Meagher, T. 2018. Maturity in a Human World. Unpublished doctoral dissertation. Storrs, CT: University of Connecticut.

Sartre, J-P. [1943] 1992. Being and Nothingness: A Phenomenological Essay on Ontology. Barnes, H.E. (trans.). (Introduction.). New York: Washington Square Press.

Wynter, S. 2003. Unsettling the Coloniality of Being/ Power/ Truth/ Freedom: Towards the Human, After Man, Its Overrepresentation Argument. The New Centennial Review 3, 3: 257 - 337.

https://doi.org/10.1353/ncr.2004.0015

Wynter, S. 2006. On How We Mistook the Map for the Territory, and ReImprisoned Ourselves in Our Unbearable Wrongness of Being. Désêtre: Black Studies Toward the Human Project. In Gordon, L.R. \& J.A. Gordon (eds.): Not Only the Master's Tools: African American Studies in Theory and Practice. New York: Paradigm/ Routledge.

https://doi.org/10.1002/9780470996645.ch9

Thomas Meagher Assistant Professor Sam Houston State University meagher.tom@gmail.com 